1 Public Health Modeling Unit and Department of Epidemiology of Microbial Diseases, Yale School of Public Health, New Haven, CT, USA

2 Center for Policy Impact in Global Health, Duke Global Health Institute, Duke University, Durham, NC, USA

Correspondence to: G Gonsalves gregg.gonsalves@yale.edu Cite this as: BMJ 2020;371:m3878 http://dx.doi.org/10.1136/bmj.m3878 Published: 06 October 2020

\section{Political interference in public health science during covid-19}

\author{
Populist leaders like Trump, Bolsonaro, Modi, and Johnson view scientists as their opponents \\ Gregg Gonsalves, ${ }^{1}$ Gavin Yamey ${ }^{2}$
}

On 26 September, Donald Trump held a lengthy ceremony at the White House to announce his nomination of Amy Coney Barrett to the Supreme Court seat left vacant by the death of Ruth Bader Ginsburg. Guests mingled inside and outside, few wore a mask, and there was little social distancing-ripe conditions for what became a superspreading event. ${ }^{1}$

Twenty eight attendees have so far tested positive for SARS-CoV-2, including the president, who was admitted to hospital and is still receiving treatment for covid-19 now that he is back at the White House. ${ }^{2}$ Just two weeks before, at an indoor rally that he held as a rebuke to covid-19 safety precautions, Trump pronounced the pandemic to be almost over, saying: "We're making that round, beautiful, last turn."3 But his magical thinking has led the US to the world's worst outbreak-with a fifth of the world's cases and deaths ${ }^{4}$-and now to the virus spreading like wildfire through the highest levels of government.

The virus reaching Trump is a grim yet inevitable conclusion to his longstanding dismissal of public health science. Trump refuses to wear a mask, mask wearing is ridiculed and scorned by many in his administration, and crowded meetings are often held inside the White House. ${ }^{5}$ He has put hundreds of White House essential workers at risk, including catering staff and groundskeepers, many of whom are people of colour and at higher risk of death if they are infected. ${ }^{6}$ Even while ill, he left the hospital in a motorcade to wave to his supporters, putting his Secret Service agents at risk. ${ }^{7}$ On arrival back at the White House, he immediately pulled off his mask and walked inside, with disregard for the health of those around him. And despite his illness he has downplayed the seriousness of covid-19, tweeting "Don't be afraid of Covid" and mistakenly saying that it is less deadly than influenza.

In the past few months, the Trump administration has become increasingly hostile to the work of public health agencies, including the Centers for Disease Control and Prevention (CDC) and the Food and Drug Administration. Trump's appointees repeatedly asked the CDC to "revise, delay and even scuttle weekly reports on the coronavirus that they believed were unflattering to President Trump." ${ }^{8}$ Political appointees were also behind the discredited, anti-scientific guidance posted to the CDC website in late August that advised against any testing of asymptomatic people. ${ }^{9}$ According to the New York Times, the guidance was "not written by CDC scientists and was posted to the agency's website despite their serious objections."9
Trump also pressured the FDA to grant emergency use authorisation of convalescent plasma, ${ }^{10}$ despite the lack of randomised trial evidence. ${ }^{11}$ The FDA wanted to adopt new, more stringent standards for authorising a covid-19 vaccine in order to strengthen public trust, but Trump has now blocked such standards. ${ }^{12}$

What Trump has failed to do is to adopt a federal response based on science. New daily cases are rising again in most of the country's states and are averaging close to 45000 a day nationwide, an increase of $8 \%$ from the average two weeks ago. ${ }^{4}$ There are no plans to scale up testing or contact tracing, nor to equip schools that have reopened with protective measures against outbreaks.

\section{Bad company}

Trump is not the only leader to reject science, downplay the covid-19 crisis, and try to manufacture good news. He is joined by Brazil's Jair Bolsonaro, India's Narendra Modi, and the UK's Boris Johnson, illiberal populist men who lead nations that have the second, third, and fifth highest number of covid-19 deaths, respectively. ${ }^{4}$ Bolsonaro fired his health minister in April for advocating social distancing measures. ${ }^{13}$ Modi has clamped down on the media for being too pessimistic about the country's epidemic, ${ }^{14}$ while the Indian Council on Medical Research, trying to please him, suggested in early July that they would have a vaccine ready by 15 August, India's Independence Day. ${ }^{15}$ After Johnson's chief adviser, Dominic Cummings, breached lockdown rules, Johnson repeatedly supported his actions and stopped reporters from asking the chief scientific adviser, Patrick Vallance, and the chief medical officer, Chris Whitty, for comments on the breach. ${ }^{16}$

How do we make sense of the disconnect between the facts on the ground in these countries and their leaders' retelling of reality? ${ }^{17}$ Rational, fact based critiques of their performance seem not to matter to them. Philosopher Jason Stanley and historian Federico Finchelstein argue that narrative coherence and common sense are beside the point with such strong men. ${ }^{18}$ In an interview with Stanley, he told us, "The only authority for these figures is that of the leader. Epistemic authority is seen as a challenge to the one authority they recognise. It's seen as a threat. So, they are inclined from the start to view scientists as their opponents."

In her 1967 essay Truth and Politics, the philosopher Hannah Arendt said, "Unwelcome opinion can be argued with, rejected, or compromised upon, but unwelcome facts possess an infuriating stubbornness that nothing can move except plain lies."19 Trump's 
evasions continue even now, about the severity of his medical condition, and when and where he was diagnosed..$^{20}$

But scientists should not lose hope. The South African president Thabo Mbeki, another science denialist, refused to provide antiretroviral medicines to his citizens, resulting in over 350000 AIDS deaths..$^{21}$ And yet after Mbeki's departure, South Africa rebooted its AIDS response and now has the largest AIDS treatment programme in the world..$^{22}$ That is the playbook we can use for restoring public health science.

Competing interests: We have read and understood BMJ policy on declaration of interests and declare the following interests: $\mathrm{GG}$ declares that he is a registered Democrat, has donated to the presidential campaign of Senator Elizabeth Warren, and will vote for Joe Biden in the 2020 US presidential election. GY is a registered Democrat, donated to the presidential campaign of Barack Obama, supported Senator Elizabeth Warren in the 2020 Democratic Party presidential primary campaign, and will vote for Joe Biden in the 2020 US presidential election.

Provenance and peer review: Commissioned; not externally peer reviewed.

1 Buchanan L, Gamio L, Leatherby L, Stein S, Triebert C. Inside the White House event now under COVID-19 scrutiny. New York Times 2020 Oct 3. https://www.nytimes.com/interac-

tive/2020/10/03/us/rose-garden-event-covid.html

2 Walker PJ. Covid-19 at the White House, 4 Oct 2020. https://public.tableau.com/profile/peter.james.walker\#!/vizhome/COVID-19attheWhiteHouse-ContactTracking/OverviewDash

3 Gearan A, Dawsey J. Trump's first indoor rally in months staged as a rebuke to coronavirus restrictions. Washington Post 2020 Sep 14. https://www.washingtonpost.com/politics/trumpnevada-rally-coronavirus/2020/09/14/82af86f0-f682-11ea-be57-d00bb9bc632d_story.html

4 Johns Hopkins coronavirus resource centre. https://coronavirus.jhu.edu/map.html

5 Eban K. "I don't give a shit about that": inside the White House, cavalier disregard created a covid petri dish. Vanity Fair 2020 Oct 2. https://www.vanityfair.com/news/2020/10/inside-the-whitehouse-cavalier-disregard-created-a-covid-petri-dish

6 CDC. Covid-19 hospitalization and death by race/ethnicity, 18 Aug 2020. https://www.cdc.gov/coronavirus/2019-ncov/covid-data/investigations-discovery/hospitalizationdeath-by-race-ethnicity.html

7 Yeo PK. Covid-positive trump ignores CDC advice to take joyride, with grim secret service agents in tow. Daily Beast 2020 Oct 4. https://www.thedailybeast.com/covid-positive-trump-ignorescdc-advice-to-take-joyride-with-grim-secret-service-agents-in-tow

8 Weiland N, Stolberg SG, Goodnough A. Political appointees meddled in CDC's "holiest of the holy" health reports. New York Times2020 Sep 12. https://www.nytimes.com/2020/09/12/us/politics/trump-coronavirus-politics-cdc.html

9 Mandavilli ACDC. Testing guidance was published against scientists' objections. New York Times 2020 Sep 17. https://www.nytimes.com/2020/09/17/health/coronavirus-testing-cdc.html

10 Florko N. FDA, under pressure from Trump, authorizes blood plasma as Covid-19 treatment. STAT2020 Aug 23. https://www.statnews.com/2020/08/23/fda-under-pressure-from-trumpexpected-to-authorize-blood-plasma-as-covid-19-treatment/

11 Estcourt LJ, Roberts DJ. Convalescent plasma for covid-19. BMJ2020;370:m3516. doi: 10.1136/bmj.m3516 pmid: 32933945

12 La Freniere S, Weiland N. White House blocks new coronavirus vaccine guidelines. New York Times 2020 Oct 5. https://www.nytimes.com/2020/10/05/us/politics/coronavirus-vaccineguidelines.html

13 Phillips D. Bolsonaro fires popular health minister after dispute over coronavirus response. Guardian 2020 Apr 16. https:/www.theguardian.com/world/2020/apr/16/bolsonaro-brazilpresident-luiz-mandetta-health-minister

14 COVID-19 in India: the dangers of false optimism. Lancet 2020;396:867. doi: 10.1016/S0140-6736(20)32001-8 pmid: 32979962

15 Kumar P. Medical body ICMR's clarification as August 15 vaccine target triggers backlash. NDTV 2020 Jul 4. https://www.ndtv.com/india-news/coronavirus-vaccine-medical-body-icmrs-clarification-as-aug-15-target-triggers-backlash-2257185

16 Johnson blocks scientists from answering "political" questions-video. Guardian 2020 May 28.https://www.theguardian.com/politics/video/2020/may/28/johnson-blocks-scientists-fromanswering-political-questions-at-coronavirus-briefing-video

17 CBS News. September 29 2020. Trump defends his response to coronavirus pandemic https://www.cbsnews.com/video/trump-defends-his-response-to-coronavirus-pandemic/

18 Finchelstein F, Stanley J. The fascist politics of the pandemic. Project Syndicate 2020 May 4. https://www.project-syndicate.org/commentary/coronavirus-fuels-fascist-politics-by-federicofinchelstein-and-jason-stanley-2020-05

19 Arendt H. Truth and politics. New Yorker 1967. Feb 25. https://idanlandau. files.wordpress.com/2014/12/arendt-truth-and-politics.pdf

20 Baker $\mathrm{P}$, Haberman M. Trump's symptoms described as “very concerning” even as doctors offer rosier picture. New York Times 2020 Oct 3. https:/www.nytimes.com/2020/10/03/us/politics/trump-covid-updates.html?action=click\&module=Spotlight\&pgtype=Homepage
21 Chigwedere P, Seage GR, 3rdGruskin S, Lee TH, Essex M. Estimating the lost benefits of antiretroviral drug use in South Africa. J Acquir Immune Defic Syndr 2008;49:410-5. doi: 10.1097/QAl.0b013e31818a6cd5 pmid: 19186354

22 Gonsalves G. Covid-19 in the US-the new disease denialism. BMJ Opinion, 14 Sep 2020. https://blogs.bmj.com/bmi/2020/09/14/gregg-gonsalves-covid-19-in-the-us-the-new-diseasedenialism/

This article is made freely available for use in accordance with BMJ's website terms and conditions for the duration of the covid-19 pandemic or until otherwise determined by BMJ. You may use, download and print the article for any lawful, non-commercial purpose (including text and data mining) provided that all copyright notices and trade marks are retained. 